\title{
About the presence of Crocidura suaveolens group (Soricomorpha, Soricidae) on Astipalaia Island (Dodecanese, Greece)
}

\author{
Francesco M. Angelici ${ }^{1 *}$, Cristina Cattaneo ${ }^{2}$, Mauro Grano ${ }^{3}$, Armando Nappi ${ }^{4}$
}

\begin{abstract}
The presence of Crocidura sp. on Astipalaia Island was shown, for the first time, in the nineties of the twentieth century. After the re-examination of the already available specimens and the analysis of the more recent material, it emerged that this insular shrew population refers to Crocidura suaveolens group. The presence of this taxon is also reported for the neighboring island of Amorgos. The presence of Crocidura suaveolens group in the Mediterranean islands is a result of Pleistocene survivors as well as human introductions, a both morphometric and genetics investigation on these specimens is deserving of further insights.
\end{abstract}

Key words: Crocidura suaveolens, Astipalaia, Eastern Mediterranean, biogeography.

Riassunto - Sulla presenza del gruppo Crocidura suaveolens (Soricomorpha, Soricidae) sull'isola di Stampalia (Dodecaneso, Grecia).

La presenza del genere Crocidura era già nota sull'isola di Stampalia dal 1992, anche se dai resti dei crani e delle mandibole ritrovati in borre di barbagianni e civetta non era stato possibile identificare la specie. In questo lavoro è stato riesaminato tutto il materiale, aggiungendone anche altro raccolto più recentemente e ne è stata accertata l'appartenenza al gruppo Crocidura suaveolens. La presenza di C. suaveolens nelle isole del Mediterraneo può essere interpretata come una sopravvivenza di fauna Pleistocenica e/o come risultato di introduzioni umane passive. Sarebbero auspicabili indagini biomolecolari e morfometrico-comparative.

Parole chiave: Crocidura suaveolens, Stampalia, Mar Egeo, biogeografia.

\section{INTRODUCTION}

The presence and the taxonomic status of genus Crocidura from Eastern Mediterranean, was longer controversial.

\footnotetext{
${ }^{1}$ FIZV, Via Marco Aurelio 2, 00184 Roma, Italia

2 Via Eleonora d'Arborea 12, 00162 Roma, Italia

${ }^{3}$ Via Valcenischia 24, 00141 Roma, Italia

${ }^{4}$ Museo Civico di Storia Naturale, Via Cortivacci 2, 23017

Morbegno (SO), Italia

* Corresponding author: francescomariaangelici@gmail.com

(C) 2018 Francesco M. Angelici, Cristina Cattaneo, Mauro Grano, Armando Nappi
}

Received: 27 March 2017

Accepted for publication: 24 July 2017
Catzeflis et al. (1985) and Vogel et al. (1986), after chromosomal, biochemical and morphological analyses, show that $C$. russula monacha Thomas, 1906, from Turkey, Syria, Lebanon and Israel belongs to C. suaveolens.

C. r. gueldenstaedti Pallas, 1811, from Turkey, proposed as incertae sedis by Catzeflis et al. (1985), was more recently placed to $C$. suaveolens group, as a separate species (Zaitsev, 1991; Bannikova et al., 2006; Vogel et al., 2003) or a subspecies of $C$. suaveolens (Hofmann, 1996; Dubey et al., 2006; 2007). On the basis of the genetics data, this taxon can be considered as occurring in Turkey, Crete, Georgia (Dubey et al., 2006), Israel, western Syria, and western Iran (Dubey et al., 2007).

In fact, a study carried out upon samples from different localities, shows that populations of $C$. russula previously reported in Turkey, were belong to $C$. suaveolens (Kefelioğlu \& Tez, 1999).

With regard to Crete Island, C. caneae Miller, 1909, was later referred to C. russula caneae (Ellermann \& Morrison-Scott, 1951; Wettstein, 1953; Corbet, 1978), C. gueldenstaedtii caneae (Richter, 1966; 1970) and C. suaveolens (Hutterer, 1981; Vogel et al., 1986). C. ariadne Pieper, 1979, also described from Crete, according to Hutterer (1981) is perhaps a juvenile of C. suaveolens. C. russula zimmermanni Wettstein, 1953 was considered a distinct species by Vermanis \& Kahmann (1978), as confirmed by Vogel (1986) and Vogel et al. (1986) from genetics data. This last one is an endemic and endangered species by Crete.

On the basis of the recent knowledge's, the Crocidura populations present in the Ionian, and Aegean Islands are attributable to $C$. suaveolens group, $C$. leucodon and $C$. zimmermanni (Masseti, 2012).

Remnants of skulls and jaws of Crocidura sp. were found both in barn owl (Tyto alba) pellets (Angelici \& Riga, 1994) that in little owl (Athene noctua) pellets (Angelici et al., 1997). Still it was not possible to capture a specimen alive or dead, despite the specific trapping campaigns (Angelici et al., 1992). Later, in 2015, M. Grano and C. Cattaneo have collected more barn owl pellets and remains.

The aim of this paper is to investigate the taxonomic status of this insular population. 


\section{Study area}

Astipalaia $\left(36^{\circ} 33^{\prime} 29^{\prime \prime} \mathrm{N} ; 26^{\circ} 21^{\prime} 06^{\prime \prime} \mathrm{E}\right)$ is a small Greek island belonging to the Dodecanese Archipelago, in the South Aegean Administrative region, Kalymnos Regional unit.

This island has an unusual butterfly shape and covers an area of $97 \mathrm{~km}^{2}$. Because of its shape, Astipalaia can be divided into two parts: a western half (Exo Nisi) and an eastern one (Mesa Nisi), joined by a narrow isthmus (Steno), 105 m wide (Fig. 1).

It is mainly mountainous (highest elevation $506 \mathrm{~m}$ a.s.l.) with calcareous soils on the eastern and exterior western sides, arenaceous and schistous soils in the remaining parts. The vegetation is poor and characterized by phrygana with spiny shrubs, olive-groves, orchards, vineyards and cereal growings.

From a climatic point of view, Astipalaia has a typical Mediterranean climate, with mild and rainy winters and dry summers. The available data from the National Meteorological Service (EMY) (http:// www.hnms.gr/), reported between 1977 and 2013 an average annual temperature of $19.27^{\circ} \mathrm{C}$. The average minimum temperature was recorded in February with values of $7.73^{\circ} \mathrm{C}$ and the average maximum in July, until $32.09^{\circ} \mathrm{C}$. The annual average relative humidity values are around $70.13 \%$ and the average annual rainfall recorded from 1985 to 2012 is around $400 \mathrm{~mm}$.
The smallest distance from the continent reaches 80 $\mathrm{km}$ with the Datça district of Muğla province, Turkey; the nearest isles are: Amorgos (40 km), Anáfi (43 km), Stefania $(31 \mathrm{~km})$ and $\operatorname{Kos}(42 \mathrm{~km})$. On the basis of these data, Astipalaia is one of the more "isolated" islands in the Eastern Mediterranean (Cattaneo \& Grano, 2016).

The specimens analyzed in this work were found in abandoned buildings and in three caves located in Ftera, Dhrakospilia, and in a site close Zafeiri Bay.

Ftera (427 $\mathrm{m}$ a.s.1.) is one of the highest peaks, located on the orographic axis along the western part of Astipalaia. It consists mostly of Eocene limestones and the cave is karstic, with stalactites and stalagmites formations. It is here evident an exploitation by sheeps and goats. The Dhrakospilia cave (40 m a.s.l.) is located in NW extremity of the eastern half of the island, at the base of the Aghios Thomas Mount. It consists of Cretaceous limestones, as the NE side of the island (Leontaris, 1974). The cave close Zafeiri (100 $\mathrm{m}$ a.s.l.) is placed on the CE edge. It is constituted of clay and shows several niches often used as perches by raptors. This sites are characterized essentially by a phryganic vegetation whose most representative species are Sarcopoterium spinosum, Thymbra capitata, Salvia fruticosa, Genista acanthoclada and Calicotome villosa. Only in the close proximity of the cave of the Zafeiri bay is present a monospecific maquis based on Juniperus phoenicea with the occasional presence of Pistacia lentiscus (Cattaneo \& Grano, 2016).

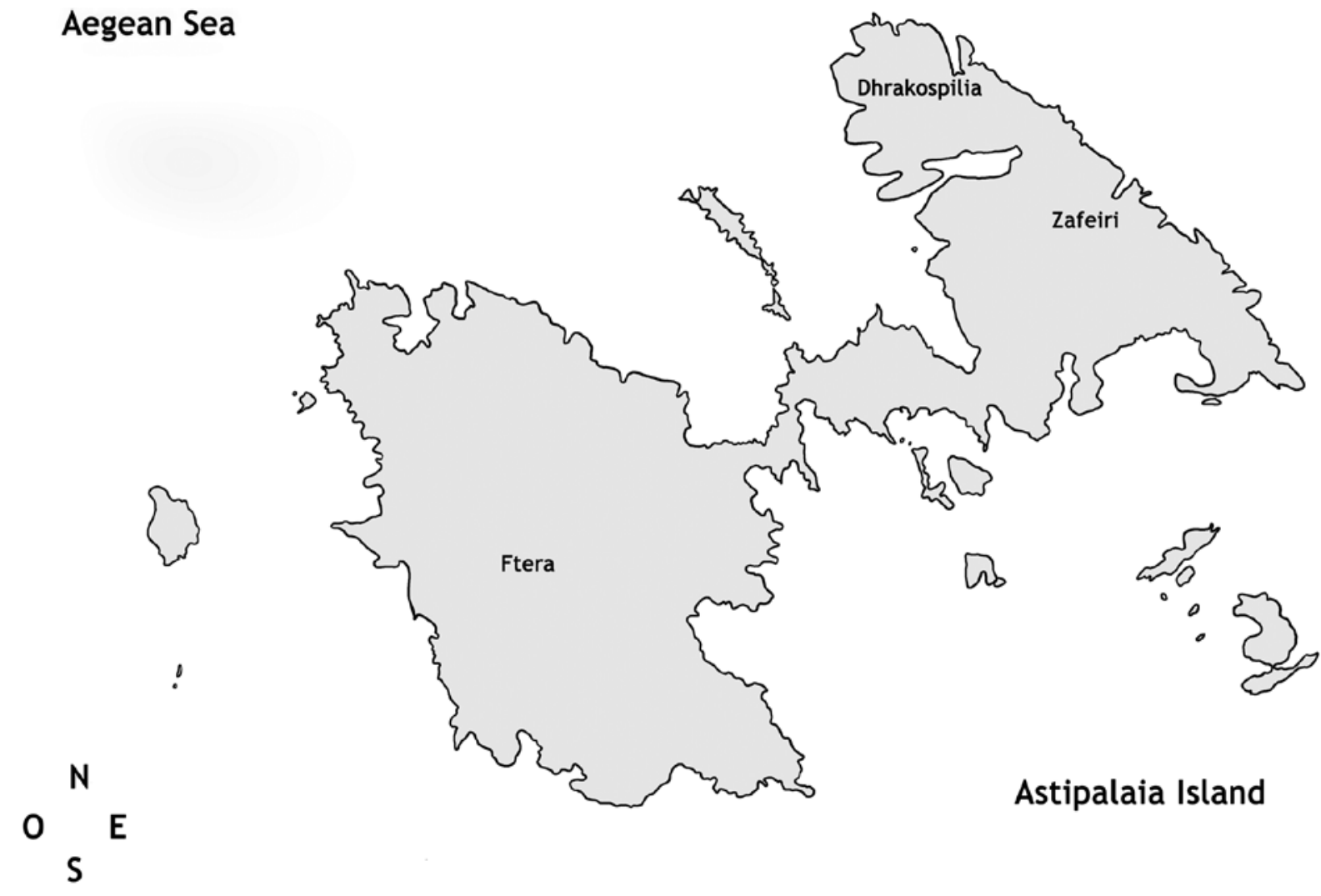

Fig. 1 - Astipalaia Island. 


\section{MATERIALS AND METHODS}

The analyzed material consists of skulls and jaws from barn owl (Tyto alba) and little owl (Athene noctua) pellets. Zygomatic breadth and mandibular height was measured by a caliper of $1 / 100 \mathrm{~m}$ precision, the values was later approximated at $1 / 10 \mathrm{~mm}$.

Little owl pellets were collected (June 1990) in abandoned buildings and in a few rocky site (Angelici et al., 1997). First collection of barn owl pellets were found (Angelici et al., 1992; Angelici \& Riga, 1994) on a calcareous wall near an empty creek and in a ruin located inside an olive tree plantation. All first barn owl pellet collections were found in September 1988, and in June, and August 1990. The following, more recent collection dates, are: 03-August-2015 (Ftera), 13-August-2015 (Dhrakospilia and Zefeiri bay).

The identification was carried out according to Niethammer \& Krapp (1990) and Kryštufek \& Vohralík (2001).

\section{RESULTS AND DISCUSSION}

The pellets analysis provided us 60 skulls, 104 right and 87 left hemi-mandibles. 7 skulls, 7 right hemi-mandibles and 5 left hemi-mandibles were not measurable; 1 right hemi-mandibles were not determinable.

The values of the zygomatic width and of the hemimandibles height are summarized in Tab. 1.

Tab. 1 - The considered measurements of the Crocidura samples from Astipalaia. ZW: zygomatic width; $\mathrm{HH}$ : hemimandible height.

\begin{tabular}{|l|c|c|c|}
\hline & ZW & HH right & HH left \\
\hline N. & 55 & 99 & 82 \\
\hline Min & 5.1 & 3.8 & 3.9 \\
\hline Max & 5.9 & 4.6 & 4.5 \\
\hline Average & 5.5 & 4.2 & 4.2 \\
\hline
\end{tabular}

On the basis of the considered measurements as well as of some morphological characters such as the shape of the zygomatic bones, of the upper premolar, of the articular and angular processes of the jaw, together with measurements carried out, we can say that the skulls and the jaws belong to $C$. suaveolens group. Further investigation will be needed to determine the exact taxonomic status of this population.

The finding of a good number of specimens, in fresh and intact pellets collected from 1988 to 2015 in more sites, allows to state that on the Astipalaia Island there is a stable shrew population. In fact, these cannot be considered as some predations on other islands or on the mainland, by erratic raptors, as sometimes it can happen (Nappi, 2011), with a subsequent emission of the pellets at Astipalaia. For instance, the study carried out by Angelici \& Riga (1994) from barn owl pellets, shows that Crocidura is representing the $22.0 \%$ of the captured preys $(n=141)$.
C. suaveolens (Pallas, 1811) is a shrew showing a wide distribution across the Palaearctic, from the Atlantic coast of Iberian Peninsula extending eastwards through Europe and Asia to Siberia (Hutterer et al., 2008). At present, among the Ionian, and Aegean Islands, C. suaveolens is reported from Corfu, Zakynthos, Kythera, Euboea, Crete, Theodorou, Rhodes, Amorgos, Kos, Samos, Psara, Chios, Lesbos, Samothrace and Thasos (Masseti, 2012; Cheke, pers. comm.).

On the basis of a recent research, carried out by analysing mitochondrial cytochrome $b$ gene, around the Mediterranean basin, the insular presence of Crocidura suaveolens group is a result of Pleistocene survivors as well as human introductions (Dubey et al., 2007), an investigation on Astipalaia specimens will be interesting.

\section{Acknowledgments}

We are grateful to Anthony Cheke for having made available its material and occurrence data about Crocidura suaveolens, still unpublished, on the island of Amorgos. To Augusto Cattaneo for providing us valid collaborative contacts and to Gabriella Bianchi for their availability.

\section{REFERENCES}

Angelici F.M. \& Riga F., 1994 - Primi dati sull'alimentazione del Barbagianni Tyto alba nell'isola di Stampalia (Dodecaneso, Grecia). Atti del VI Convegno Italiano di Ornitologia, Torino, 8-11 ottobre 1991, 419-420.

Angelici F.M., Latella L., Luiselli L. \& Riga F., 1997 The summer diet of the Little Owl Athene noctua on the island of Astipalaia (Dodecanese, Greece). Journal of Raptor Research, 31: 280-282.

Angelici F.M., Pinchera F. \& Riga F., 1992 - First record of Crocidura sp. and Mus domesticus and notes on the mammals of Astipalaia Island (Dodecanese, Greece). Mammalia, 56: 159-161.

Bannikova A.A., Lebedev V.S., Kramerov D.A. \& Zaitsev M.V., 2006 - Phylogeny and systematics of the Crocidura suaveolens species group: corroboration and controversy between nuclear and mitochondrial DNA markers. Mammalia, 70: 106-119.

Cattaneo C. \& Grano M., 2016 - Contribution to the knowledge of vascular flora on Astypalea Island (Dodecanese, Greece). Phytologia Balcanica, 22 (3): 405417.

Catzeflis F., Maddalena T., Hellwing S. \& Vogel P., 1985 Unexpected findings on the taxonomic status of East Mediterranean Crocidura russula auct. (Mammalia, Insectivora). Zeitschrift für Säugetierkunde, 50: 185201.

Corbet G.B., 1978 - The Mammals of the Palearctic Region: a taxonomic review. British Museum (Natural History) and Cornell University Press, London, 314 pp.

Dubey S., Cosson J.F., Magnanou E., Vohralík V., Benda P., Frynta D., Hutterer R., Vogel V. \& Vogel P., 2007 Mediterranean populations of the lesser white-toothed shrew (Crocidura suaveolens group): an unexpected puzzle of Pleistocene survivors and prehistoric introductions. Molecular Ecology, 16: 3438-3452. 
Dubey S., Zaitsev M., Cosson J.F., Abdukadier A. \& Vogel P., 2006 - Pliocene and Pleistocene diversification and multiple refugia in a Eurasian shrew (Crocidura suaveolens group). Molecular Phylogenetics and Evolution, 38: 635-647.

Ellerman J.R. \& Morrison-Scott T.C.S., 1951 - Checklist of Palearctic and Indian Mammals. 1758 to 1946. British Museum, London.

Hoffmann R.S., 1996 - Noteworthy shrews and voles from the Xizang-Qinghai plateau. In: Contributions in Mammalogy: a memorial volume honoring Dr. J. Knox Jones Jr. Genoways H.H. \& Baker R.J. (eds.). Museum of Texas Tech University, Lubbock, TX: 155168.

Hutterer R., 1981 - Der status von Crocidura ariadne Pieper, 1979 (Mammalia: Soricidae). Bonner Zoologische Beiträge, 32: 3-12.

Hutterer R., Amori G., Kryštufek B., Yigit N., Mitsain G. \& Palomo L.J., 2008 - Crocidura suaveolens. The IUCN Red List of Threatened Species 2008. <www. iucnredlist.org $>$ (retrieved on December 2015).

Kefelioğlu H. \& Tez C., 1999 - The distribution problem of Crocidura russula (Hermann, 1780) (Mammalia: Insectivora) in Turkey. Turkish Journal of Zoology, 23: 247-251.

Kryštufek B. \& Vohralík V., 2001 - Mammals of Turkey and Cyprus. Introduction, Checklist, Insectivora. Knjižnica Annales Majora.

Leontaris S.N., 1974 - Investigations of the geomorphology and geology of Astypalaia island (Dodecanese). Annales géologiques des pays Helléniques, 25: 33104.

Masseti, M. 2012 - Atlas of terrestrial mammals of the Ionian and Aegean islands. De Gruyter, Berlin/Boston.

Nappi A. 2011 - L'analisi delle borre degli uccelli: metodiche, applicazioni e informazioni. Un lavoro monografico. Picus, 37: 106-120.

Niethammer J. \& Krapp F., 1990 - Handbuch der Säugetiere Europas. Band 3/I. Insektenfresser-Insectivora, Herrentiere-Primates. Akademische Verlagsgesellschaft, Wiesbaden.

Richter H., 1966 - Eine Serie Crocidura gueldenstaedti (Pallas, 1811) (Mammalia, Insectivora) von der griechischen Insel Samos. Beaufortia, 13 (157): 109115.

Richter H., 1970 - Zum taxonomischen Status der zwei Crociduren-Formen von Kreta (Mammalia, Insectivora, Soricidae). Zoologische Abhandlungen aus dem staatlichen Museum für Tierkunde in Dresden, 31: 279-291.

Vesmanis I. \& Kahmann H., 1978 - Morphometrische Untersuchungen an Wimperspitzmausen (Crocidura) 4. Bemerkungen iiber die Typusreihe der kretaischen Crocidura russula zimmermanni Wettstein, 1953 im Vergleich mit Crocidura gueldenstaedti caneae (Miller, 1909). Saugetierkundliche Mitteilungen, 26: 214222.

Vogel P. 1986 - Der Karyotyp von Crocidura zimmermanni Wettstein, 1953 (Mammalia, Insectivora). Bonner zoologische Beiträge, 37: 35-38.
Vogel P., Cosson J.F. \& Jurado L.F.L., 2003 - Taxonomic status and origin of the shrews (Soricidae) from the Canary Islands inferred from a mtDNA comparison with the European Crocidura species. Molecular Phylogenetics and Evolution, 27: 271-282.

Vogel P., Maddalena T. \& Catzeflis F., 1986 - A contribution to the taxonomy and ecology of shrews (Crocidura zimmermanni and C. suaveolens) from Crete and Turkey. Acta Theriologica, 31 (39): 537-545.

von Wettstein O., 1953 - Die Insectivora von Kreta. Zeitschrift für Säugetierkunde, 17: 4-13.

Zaitsev M.V., 1991 - Species composition and questions of systematics of white-toothed shrews (Mammalia, Insectivora) of the fauna of USSR. In: Questions of systematics, faunistics and paleontology of small mammals. Zaitsev M.V. (ed.). Proceedings of the Zoological Institute Russian Academy of Sciences, 243: 3-46. 